\title{
Guadalupe Gómez-Ferrer, Gabriela Cano, Dora Barrancos e Asunción Lavrin (Coord.). Historia de las Mujeres en España y América Latina: del siglo XX a los umbrales deI XXI
}

Silvia Maria Fávero Arend*

Madrid: Cátedra, 2006. v.4, 981p.

A coletânea Historia de las Mujeres en España y América Latina, composta de quatro volumes dirigidos por Isabel Morant e lançados em 2005 e 2006, é considerada uma importante referência para o estudo da História das mulheres e das relações de gênero. Esse monumental empreendimento (v.1, De la prehistoria a edad media, 2005; v.2, El mundo moderno, 2005; v.3, Del siglo $X I X$ a los umbrales del XX, 2006), levado a cabo por um conjunto de historiadoras e historiadores dos dois continentes, propõe-se a analisar as experiências das mulheres que viveram em territórios que atualmente são conhecidos como América Latina e Espanha, desde a denominada Pré-História até o final do século XX, bem como os discursos emitidos por diferentes atores sociais sobre as relações de gênero vigentes nessas sociedades no período. Nesta resenha, em função da extensão das obras, realizaremos comentários somente sobre os 41 artigos do quarto volume, que abordam "as transformações verificadas na vida das mulheres durante o século XX”. Na Introdução da parte relativa à Espanha, Guadalupe Gómez-Ferrer sintetiza os objetivos perseguidos pelos articulistas:

Dar cuenta de esos cambios que se han producido en la vida de las mujeres $y$ de su protagonismo en la tarea de romper los obstáculos que se oponían a la igualdad entre los sexos en el plano social, civil y politico, en una sociedad dirigida por varones, que se resistía más o menos conscientemente a ver cuestionada la autoridad masculina. (Gómez-Ferrer, "Introducción”, p.16)

\footnotetext{
* Programa de Pós-graduação em História, Universidade do Estado de Santa Catarina (Udesc). Rua Visconde de Ouro Preto, 457, Centro.88020-040 Florianópolis - SC - Brasil. silvia@newsite.com.br.
} 
A periodização da história política da Espanha e o discurso Feminista são os "fios condutores" das reflexões da primeira parte do volume. O debate ocorrido na sociedade espanhola, nas décadas iniciais do século XX, acerca da luta pela conquista dos direitos políticos das mulheres é o tema central de parte dos artigos. Inmaculada Blasco, Rosa Maria Capel, Mary Nash e Mercedes Yusta procuram identificar as diferenças existentes entre os discursos das feministas católicas, das socialistas e das anarquistas. Para as católicas, norteadas pelo ideário liberal conservador, a luta por direitos políticos era sinônimo de voto feminino. Já para os outros dois grupos, o campo dos direitos políticos era muito mais amplo, abrangendo problemas suscitados pelo mundo do trabalho e relativos à igualdade civil. A introdução no texto constitucional, em 1931, do sufrágio feminino e de outros direitos civis e trabalhistas foi resultado desses embates. Todavia, com a mudança do cenário político, em 1939, grande parte dessas conquistas foi 'esquecida'.

Em outro conjunto de artigos, Giuliana di Febo, Suzana T. Garcia e Teresa R. de Lecea demonstram a importância, para a manutenção do regime ditatorial franquista, das ações das mulheres filiadas à Sección Feminina de Falange. $\mathrm{O}$ discurso da mãe-esposa-dona-de-casa difundido pelas falangistas e pela Igreja católica começou a ser questionado somente a partir do final da década de 1960, quando as mulheres das camadas médias e urbanas ingressaram em grande número no mercado de trabalho, especialmente no setor terciário. As agendas do feminismo da segunda onda relativas à dupla jornada de trabalho e ao controle da natalidade, bem como à participação das mulheres (inclusive da rainha Sofia) no processo de redemocratização da Espanha constitui-se na temática de outra parcela de artigos. A polifonia feminista da década de 1990 - do mundo acadêmico, dos movimentos sociais e dos setores sindicais - e as questões referentes à saúde reprodutiva das mulheres e à terceira idade, associadas ao discurso da terceira onda, são debatidas nos últimos artigos dessa parte do volume.

Quanto à América Latina o grande desafio das articulistas estava em encontrar 'pontos de contato' nas experiências vivenciadas pelas mulheres em sociedades distintas. O discurso feminista articulado ao da modernização socioeconômica cumpre esse papel na obra. Diferente do verificado para a Espanha, nesta segunda parte do volume observamos um maior equilíbrio entre as narrativas produzidas sob o enfoque da história política e da história social. O primeiro conjunto de artigos discute a emergência e a difusão do discurso feminista da primeira onda nos vários paises do continente, entre 1900 e 1950. Foram, sobretudo, mulheres escolarizadas pertencentes às camadas médias e altas que lutaram pelo sufrágio feminino e por outros direi- 
tos sociais na Argentina, Uruguai, Peru, Colômbia, México, países da América Central e Brasil. Por essa dimensão social considera-se, atualmente, que os resultados dessas ações foram 'limitados'. Dentre essas análises destaca-se a de Raquel Soihet acerca do Brasil. A autora construiu sua narrativa buscando realizar um diálogo historiográfico entre as abordagens das brazilianistas e das historiadoras brasileiras. Enquanto as primeiras, muitas vezes, olham o processo a partir de periodizações e problemas vigentes na Europa e na América do Norte, as segundas procuram descrever as singularidades brasileiras. Os Congressos Internacionais, organizados nas grandes cidades da região ao longo daquelas décadas, onde se verificava a difusão de discursos relativos à norma familiar burguesa e à infância, foi outro aspecto desse processo salientado pelas historiadoras.

As reflexões sobre a participação de mulheres latino-americanas nos movimentos sociais são o 'ponto alto' dessa parte do volume, pois demonstram quão plurais eram as identificações de classe, etnia, religiosidade e partidárias das protagonistas, gerando assim embates em campos muito distintos. Margareth Power analisa a participação das mulheres das camadas médias brasileiras e chilenas na deposição de João Goulart e Salvador Allende. Por sua vez, Suzana Bianchi descreve as várias fases do movimento das Mães da Praça de Maio, bem como sua importância para a queda do regime autoritário na Argentina. Já Lynn Stoner discute as dificuldades enfrentadas pelas socialistas cubanas no interior do Partido Comunista, onde os quadros eram em grande parte masculinos e, com certa freqüência, professavam um ideário machista. Eugenia Bridikhina narra as lutas das mulheres bolivianas mineiras e camponesas por melhores condições de vida. Por sua vez, os artigos de Mirta Zaida Lobato, Luz Gabriela Arango e Maria Teresa Fernández Aceves sobre as relações de trabalho femininas nas sociedades argentina, uruguaia, colombiana, equatoriana e mexicana abordam uma ampla gama de problemas, tais como, as mudanças na divisão sexual do trabalho no interior da família, a legislação trabalhista e os setores da economia onde as mulheres estavam inseridas.

O último conjunto de artigos do volume propõe-se a efetuar um 'balanço’ dos rumos do feminismo no continente, no final do século XX. Nestas reflexões fica patente o estágio em que se encontra o discurso acadêmico sobre a temática nos países latino-americanos. Margareth Rago, além de analisar os impactos do discurso feminista da segunda e da terceira ondas na sociedade brasileira, responsáveis em grande parte pela edificação de um conceito de cidadania que leva em conta múltiplos sujeitos (desde as mulheres pobres afrodescendentes, passando pelas homossexuais até as executivas das multinacionais), enuncia as possibilidades da criação de outro paradigma epistemológico. 
A autora traz então para a cena os debates teóricos e políticos realizados no campo das relações de gênero e que estão sistematizados na produção bibliográfica recente do país. Segundo ela, esses debates estão presentes na Revista de Estudos Feministas, nos Cadernos Pagu, na Revista Espaço Feminino e na Revista Eletrônica Lybris (p.878). Marta Lamas e Margarita Iglesias Saldaña apresentam uma interpretação desse mesmo processo, ressaltando as singularidades dos casos mexicano e peruano.

Obras dessa magnitude são passíveis de inúmeras considerações críticas. O conjunto de artigos fornece para o leitor ou leitora um panorama do vivido pelas mulheres que habitaram a Espanha e a América Latina ao longo do século XX. Esse panorama do ponto de vista teórico foi elaborado a partir das clivagens de classe, etnia, dimensões do rural ou do urbano, religiosidade, grau de escolarização, ideário político etc. Nesse mesmo sentido, há um grande esforço das historiadoras na tentativa de compreender quais são os pilares constitutivos do discurso feminista da primeira, segunda e terceira ondas que vicejou nessas sociedades no período, bem como as diferentes ações engendradas por ele. A vasta e atualizada bibliografia a que as articulistas recorrem nessa tarefa também merece destaque.

Parte das narrativas, especialmente as presentes na primeira parte do volume, foi edificada sob o enfoque da história política de cunho factual, centrada nas grandes personagens e sem menção às fontes documentais. Porém, o que realmente gera grande inquietação no leitor é o fato de a periodização da história político-institucional dos Estados Nacionais (sobretudo no caso da Espanha) ser tomada como marco referencial para a História das mulheres. Não se está reivindicando devidamente uma abordagem totalmente autônoma desses referenciais temporais, mas sim que os processos protagonizados pelas mulheres sejam os balizadores da interpretação a ser feita pelos pesquisadores. Aliás, atuando nesta direção o discurso historiográfico poderá se aproximar do mencionado por Margareth Rago na própria obra, ou seja, colaborar para a gênese de outro paradigma.

Por fim, uma questão: fueron cien años de soledad? Guiomar DueñasVargas, em seu texto acerca dos embates travados pelas mulheres sob o signo do Feminismo no século XX, responde: definitivamente, no. O horizonte permaneceu sendo a construção coletiva de sociedades mais igualitárias de ambos os lados do Atlântico.

Resenha recebida em dezembro de 2007. Aprovada em dezembro de 2007. 